\title{
Càlcul casolà de la velocitat del so
}

\author{
Albert Bramon \\ IES-SEP la Garrotxa, Olot \\ abramon@xtec.cat
}

Es proposa un mètode senzill per determinar amb pocs mitjans la velocitat del so a l'aire.

\section{MÈTODE}

Es tracta de situar-se a uns 50 o 100 metres d'una paret on sentim l'eco i començar a acostumar-nos a sentir-lo nítidament.

Amb les mans o amb l'ajuda d'algun aparell que faci un so sec ens posarem a picar de forma regular escoltant el so de l'eco. Hem de començar amb un ritme lent $\mathrm{i}$ anar augmentant aquest ritme progressivament.

Arribarà un moment que el ritme de les picades aconseguirà tapar l'eco, és a dir, que el so de la picada coincidirà amb l'eco de l'anterior. En aquest moment, hem de mantenir el ritme i un company nostre ha de mesurar amb un cronòmetre senzill el temps que duren 20 picades consecutives.
Adoneu-vos que, en aquest moment, el so tarda el mateix temps per anar i tornar de la paret que el temps que passa entre picada i picada.

Un cop feta aquesta mesura i amb l'ajuda d'una cinta mètrica mesurarem la distància a la paret en metres i centímetres.

L'últim pas és calcular la velocitat dividint la distància que el so ha recorregut pel temps que ha trigat en fer-ho.

Per millorar la mesura repetirem aquest exercici des de quatre distàncies diferents i en calcularem la mitjana i la desviació mitjana.

(Recordeu que per evitar arrossegar inútils carretons de xifres, només heu de fer servir en el resultat de la divisió tantes xifres com la mesura que menys en tenia).

\section{RESULTATS}

\begin{tabular}{|l|l|l|l|}
\hline & Distància & Temps & Velocitat \\
\hline Experiència 1 & & & \\
\hline Experiència 2 & & & \\
\hline Experiència 3 & & & \\
\hline Experiència 4 & & & \\
\hline
\end{tabular}

\begin{tabular}{|l|c|}
\hline $\begin{array}{c}\text { Mitjana de } \\
\text { velocitats }\end{array}$ & $\begin{array}{c}\text { Desviació } \\
\text { mitjana }\end{array}$ \\
\hline & \\
\hline
\end{tabular}




\section{QÜESTIONS}

1) Quin fonament físic té recobrir els llocs on es fan conferències i concerts amb cortines, cartrons, suro o escumes?

2) Digues un fet de la vida quotidiana on es vegi que la llum viatja més ràpid que no pas el so.

3) Què vol dir que un avió sigui supersònic?
4) Per quines dues raons sentim millor l'eco anant d'excursió que dins d'una ciutat?

5) Per quina raó mesurem el temps de 20 picades de mans i no només d'1?

6) Calcula la velocitat del so en $\mathrm{km} / \mathrm{h}$.

7) Calcula la velocitat de la llum en $\mathrm{m} / \mathrm{s}$ i fent servir la notació científica. 